\title{
Employment Creation and Constraints to Fish Farming in the Niger Delta Region of Nigeria
}

\author{
Robert Ugochukwu Onyeneke ${ }^{1 *}$, Felix Abinotam Iruo ${ }^{2}$ and Christopher Chiedozie Eze ${ }^{3}$ \\ ${ }^{1}$ Department of Agriculture (Agricultural Economics and Extension Programme), Alex Ekwueme Federal University Ndufu-Alike, Nigeria \\ ${ }^{2}$ Department of Agricultural Economics and Rural Sociology, Niger Delta University, Nigeria \\ ${ }^{3}$ Department of Agricultural Economics, Federal University of Technology Owerri, Nigeria
}

Submission: December 16, 2019; Published: January 06, 2020

*Corresponding author: Robert Ugochukwu Onyeneke, Department of Agriculture (Agricultural Economics and Extension Programme), Alex Ekwueme Federal University Ndufu-Alike, Ebonyi State, Nigeria

Abstract

The study analysed employment creation and constraints to fish farming in Nigeria's Niger Delta region. A combination of purposive and multistage sampling techniques was used in selecting 360 fish farmers for this study while a structured questionnaire was designed and used for data collection. Our results show that a total of 3,360 jobs were generated from fish production, fish marketing, processing and distribution as well as inputs distribution. Farmers used the income realized from fish farming to acquire assets such as land, cars, motorcycles, buildings and household facilities and provision of education to their children. High cost of feed and other inputs (92.2\%) was the major challenge facing fish farming. Research and technology on alternative cost-effective sources of feed and other inputs in the region be explored.

Keywords: Fish farming; Niger delta; Employment creation; constraints

\section{Introduction}

One important livelihood activity in Nigeria's Niger Delta region is fishing because of its contribution to employment (40$60 \%$ of the people engaged in this sector) and protein to the diets of about $50 \%$ of Nigerians [1-3]. The region is fragile and rich in crude oil. Unfortunately, the region is severely affected by oil spillage and pollution arising from crude oil exploration and exploitation of oil companies as well as conflicts and militancy activities which all have reduced the quality of the water bodies in the area with resultant effect on the production of capture fish. People of the region are, therefore, left in penury as their livelihoods are displaced. There is, therefore, the need to alleviate the poverty level of the people of the area. In light of the persistent conflict and damage to the region's environment leaving many people with no job [3-6] fish farming is serving an important livelihood and self-employment means in the area. Unfortunately, empirical evidence on the contribution of fish farming to employment creation as well as constraints to fish farming is largely scanty. There are comparatively few published works in respect of the thematic issues this research addresses regarding the employment generation impact and constraints of apparently neglected but important sector. This study, therefore, specifically determined:

a) employment generation potentials of fish farming activities in Nigeria's Niger Delta region; and

b) challenges confronting fish farmers in the area.

\section{Methodology}

Niger Delta Region of Nigeria was the study area. The region is made up of nine States - Abia, Akwa-Ibom, Bayelsa, Cross River, Delta, Edo, Imo, Ondo and Rivers States. The area constitutes about $25 \%$ of the Nigerian population [5]. A combination of purposive and multistage sampling techniques was used in selecting respondents for this study. We first selected five States (Akwa Ibom, Bayelsa, Delta, Imo and Rivers) using random sampling. The random selection of four Local Government Areas (LGAs) from each State was the second stage while the purposive selection of six villages known for the existence of fish farms was the third stage. In the final stage we randomly selected three fish farmers from each of the villages. Table 1 shows the States, Local Government Areas and Villages selected for the study. 
Table 1: States, local government areas and villages selected for the study.

\begin{tabular}{|c|c|c|}
\hline States & Local Government Areas & Villages \\
\hline \multirow{4}{*}{ 1. Akwa Ibom } & Uruan & Udon Ebom, Ekim Enen, Ikono Ufok, Mbiaya Uruan, Use' Uruan, Ekpene Ukim \\
\hline & Ikot Abasi & Ette, Ikot Nkem, Uwang, Ubufi, Ita Ewa, Ikot Abasi \\
\hline & Essien Udim & Ukana Ikot Ide, Ukana Atan, Oruk IKot Uquo, Ukana Uwa, IKot - Obio, Afaha Udim \\
\hline & Etinan & Edin Idim, Ikot Ese Oku, Edem Ekpat, Idak Okpo, Ikot Inyang Ossom, Ikot Osung \\
\hline \multirow{4}{*}{ 2. Bayelsa State } & Ogbia & Imiringi, Emeyal, Emakalakala, Opume, Otuokpoti, Anyama \\
\hline & Kolokuma/Opokuma & Odi, Sampou, Sabagria, Gbarama, Igbainwari, Orubiri \\
\hline & Sagbama & Tungbo, Ebedebiri, Toru - Angiama, Okumbiri, Sagbama, Agorogbene \\
\hline & Yenagoa & Ovom, Obogoro, Okaka - Epie, Okordia - Zarama, Tombia, Koroama \\
\hline \multirow{4}{*}{ 3. Delta State } & Ethiope East & Okure Kpo, Kokori, Oghara, Omoja, Eku, Okorome \\
\hline & Isoko South & Emede, Igbide, Uzere, Irri, Oleh, Olomoro \\
\hline & Patani & Aven, Odorubu, duophori, Ume, Toru - Angiama, Agadama \\
\hline & Oshimili North & Okpanam, Asaba, Ibusa, Anwai, Ugbolu, Akwukwu-Igbo \\
\hline \multirow{4}{*}{ 4. Imo State } & Ideato North & Osina, Umukegwu, Arondizugu, Ozuome - Urualla, Akokwa, Umuobom. \\
\hline & Okigwe & Amuro, Umulolo, Ihube, Umuna, Ezumadi, Ezinachi. \\
\hline & Ikeduru & Ugiri-Ike, Uzuoagba, Amaimo, Umukpei, Avuvu, Inyi - Ishi \\
\hline & Orlu & Umuowa, Ihitte-Owere, Okporo, Amaifeke, Umuna, Eluama \\
\hline \multirow{4}{*}{ 5. Rivers State } & Abua/Odual & Anyu, Kugbo, Amurutor, Omelema, Ogonokom, Emelego \\
\hline & Ogba/Egbema/Ndoni & Ndoni, Oboburu, Akabuka, Obirikom, Ogbogene, Obukegi \\
\hline & Ahoada West & Okogbe, Edagberi, Joinkarama, Mbiama, Olokogbe, Idu \\
\hline & Obio/Akpor & Elelewo, Eneka, Rukpoku, Eliozu, Rumuolumeni, Eliparanwo \\
\hline
\end{tabular}

A structured questionnaire was designed and used for data collection. To ensure accurate completion and retrieval of the questionnaire administered the researcher used trained enumerators who had the patience to go through the questionnaire with the respondents. The study objectives were achieved using descriptive statistics.

\section{Results and Discussion}

\section{Employment and wealth generation}

\section{Employment generation}

As shown in Table 2, the sum of the number of persons employed in direct fish production from all the respondents in 2014 was 870 persons. In 2015, the value stood at 1,700 persons meaning an increase of 830 additional jobs in the area. In 2014, the sum of the number of persons employed in fish marketing, processing and distribution was 1,150 persons. In 2015, however, it increased to 2,970 persons- an additional increase of 1,820 persons fully engaged in the business of processing, marketing and distribution of the product from the surveyed farmers. This finding is in agreement with CTA [7] which acknowledged fish farming as a fast-growing enterprise providing employment to about 250 million persons directly and indirectly through an increase in income related to fish sales and leads to improvement in household food consumption.

On input distribution, the sum of the number of persons employed in input distribution was 930 distributors in 2014 as indicated by the fish farmers sampled in the area. In 2015, the total number of employments indicated 1,640 persons involved, 
meaning additional 710 persons were gainfully engaged in the distribution of fish farming inputs. On the whole, a total of 3,360 jobs were generated by fish farming in the study area in 2015. In view of the subsistence nature of business in the region, it can be inferred that fish farming can generate employment, improve income and consumption of food, and reduce poverty.

Table 2: Employment potentials of fish farming in niger delta region.

\begin{tabular}{|c|c|c|c|}
\hline Activity & Employment at 2014 & Employment at 2015 & Number Increase \\
\hline Fish production & 870 & 1,700 & 830 \\
\hline Fish marketing processing and distribution & 1,150 & 2,970 & 1,820 \\
\hline Input distribution. & 930 & 1,640 & 710 \\
\hline Total & $\mathbf{2 , 9 5 0}$ & $\mathbf{6 , 3 1 0}$ & $\mathbf{3 , 3 6 0}$ \\
\hline
\end{tabular}

\section{Wealth generation}

Table 3: Distribution of asset acquired.

\begin{tabular}{|c|c|c|}
\hline Asset Acquired & Frequency & Percentage \\
\hline Land & 143 & 39.7 \\
\hline Car & 20 & 2.8 \\
\hline Motorcycle & 12 & 3.3 \\
\hline $\begin{array}{c}\text { Household facilities; TV-Set, DVD, } \\
\text { Fan, Radio }\end{array}$ & 290 & 80.8 \\
\hline Training/Education of children & 312 & 86.7 \\
\hline
\end{tabular}

Note: Multiple Responses.

Result in Table 3 indicated that $39.7 \%$ of the fish farmers surveyed used the income from smallholder fish farming to acquire more land for production while $2.8 \%, 3.3 \%$ and $21.1 \%$ used their income for the acquisition of cars, motorcycles, and buildings respectively. Furthermore, in Table 3, 80.8\% of the fish farmers used the income for the acquisition of household facilities/assets, such as TV set, DVD, Electric Fan, Radio etc. while others (86.7\%) used their income for the training and education of their children.

\section{Challenges facing fish farmers}

Table 4: Challenges confronting fish farmers.

\begin{tabular}{|c|c|c|}
\hline Challenge & Frequency & Percentage \\
\hline High cost of feed and other inputs & 332 & 92.2 \\
\hline Inadequacy of extension agents & 292 & 81.1 \\
\hline Shortage of skilled fishery personnel & 263 & 73.1 \\
\hline Inadequate capital/credit & 321 & 89.2 \\
\hline $\begin{array}{c}\text { Unavailability of required species of } \\
\text { fingerlings }\end{array}$ & 161 & 44.7 \\
\hline Unfavorable price of fish & 219 & 60.8 \\
\hline High mortality rate and predators & 71 & 19.7 \\
\hline
\end{tabular}

Note: Multiple Responses.

We presented the challenges confronting the farmers in Table 4. Results indicated that $92.2 \%$ of the farmers were faced with high cost of feed and other inputs. This implies that cost of feed and other inputs were major constraints facing the farmers. This result supports Adewuyi et al. [8] finding that cost of feed and fingerling were the major costs of production for fish farmers. The majority (81.1\%) of the fish farmers had inadequate contact with extension agents during the farming period. This result is in agreement with Hammed [9] that less than ten percent of the fish farmers in Osun State receive extension services from ADP. This could further be interpreted that the study area is not well equipped with innovative information disseminated by these extension agents. Furthermore, $89.2 \%$ of the smallholder fish farmers reported inadequate capital or credit facility affecting their farm business. Ugwumba \& Chukwuji [10] found similar result about the challenge of inadequate capital for fish farming. Hyuba et al. [11] also found that inadequacy of capital (89.1\%) was a major challenge to this business in Central Uganda. This implies that these fish farmers would be producing at a low output.

About $73.0 \%$ of the fish farmers identified shortage of skilled fishery personnel in their farms as one of the constraints affecting them. This may mean that the farmers were small scale and lacked the capital to acquire the services of skilled personnel. About $45 \%$ of the fish farmers surveyed mentioned the lack of availability of required species of fingerlings as a problem in their fish farming business. According to them, unavailability of standard and functional hatcheries in the area has resulted in high cost of fingerlings. Unfavorable prices of fish confirmed by $60.8 \%$ was another major constraint to fish farming in Niger Delta due mainly to uncoordinated market demand and supply forces and lack of infrastructural facilities such as storage and processing facilities, electricity and good road network. This finding is in consonance with Adeniyi et al. [12] who reported that unavailability of processing facilities affects fish farming business. Fish farmers in the region were compelled to sell their fish at reduce prices to avoid spoilage and losses. Further result in Table 4 indicated that high mortality rate and predators was reported by $19.7 \%$ of the fish farmers as a serious challenge to the enterprise in the area. This was viewed as an indicator of lack of skills and knowledge about fish farming and poor management of resource use. This result is supported by the finding of Adewuyi [13] who reported predators' attack as major constraints to fish farming. These constraints affected smallholder fish farmers in the region to operate at a very low-profit level. Consequently, 
the role of smallholder fish farming in jobs creation and poverty alleviation in the region is reduced considerably.

\section{Conclusion}

This paper concludes that fish farming has created many jobs in the area. The jobs are in the areas of fish production, fish marketing, processing and distribution as well as inputs distribution. Farmers used the income realized from fish farming to acquire assets such as land, cars, motorcycles, buildings and household facilities and provision of education to their children.

There are some constraints facing fish farming business in the region. These include; high cost of feed and other inputs, inadequate contact with of extension agents, inadequate skilled fishery personnel and inadequate capital. There should be publicprivate partnership in the area of provision and procurement fish farming inputs and make the inputs available to farmers at subsidized rates.

\section{References}

1. IPCC (2014) Climate Change 2014: Synthesis Report. Geneva: IPCC.

2. Lo AW (2012) Reading about the Financial Crisis: A Twenty-one-book Review. Journal of Economic Literature 50(1): 151-178.
3. WEF (2017) The Global Risk Report 2017.

4. Gheorghe AV, Masera M, De Vries L, Weijnen M, Kroeger W (2007) Critical infrastructures: The need for international risk governance. International Journal of Critical Infrastructures 3(1-2): 3-19.

5. Lucas K, Renn O, Jaeger C, Yang S (2018) Systemic risks: a homomorphic approach on the basis of complexity science. International Journal of Disaster Risk Science 9(3): pp. 292-305.

6. van Asselt MBA (2000) Perspectives on Uncertainty and Risk. Dordrecht and Boston: Kluwer.

7. Renn O, Klinke A (2016) Complexity, Uncertainty and Ambiguity in Inclusive Risk Governance. In: Andersen TJ (ed.), The Routledge Companion to Strategic Risk Management. Milton Park, New York: Routledge, pp. 13-30.

8. Haken H (1977) Synergetics. Berlin: Springer.

9. Prigogine I (1980) From being to becoming. San Francisco: WH Freeman.

10. Churchman CW (1967) Wicked Problems [Guest Editorial]. Management Science 14(4): B141-142.

11. Purvis B, Mao Y, Robinson D (2019) Three Pillars of Sustainability: In Search of Conceptual Origins. Sustainability Science 14: 681-695.

12. Schlüter ML, Haider LJ, Steven J, Lad SJ, Lindkvist E, et al. (2019) Capturing emergent phenomena in social-ecological systems: an analytical framework. Ecology and Society 24 (3). 